Portland State University

PDXScholar

Criminology and Criminal Justice Faculty

Publications and Presentations

$9-2013$

\title{
"Fixed" Sentencing: The Effect on Imprisonment Rates Over Time
}

Mark G. Harmon

Portland State University

Follow this and additional works at: https://pdxscholar.library.pdx.edu/ccj_fac

Part of the Criminology and Criminal Justice Commons

Let us know how access to this document benefits you.

Citation Details

Harmon, Mark G., "'Fixed" Sentencing: The Effect on Imprisonment Rates Over Time" (2013). Criminology and Criminal Justice Faculty Publications and Presentations. 15.

https://pdxscholar.library.pdx.edu/ccj_fac/15

This Post-Print is brought to you for free and open access. It has been accepted for inclusion in Criminology and Criminal Justice Faculty Publications and Presentations by an authorized administrator of PDXScholar. Please contact us if we can make this document more accessible: pdxscholar@pdx.edu. 


\title{
"FIXED" SENTENCING: THE EFFECT \\ ON IMPRISONMENT RATES OVER TIME
}

\begin{abstract}
Objective: Sentencing guidelines, statutory presumptive sentencing, determinate sentencing, truth in sentencing, and three strikes are important components of the criminal justice system. The main purpose behind a relatively-fixed sentence is to remove judicial discretion by insuring that convicted felons receive a reasonably-assumed sentence depending on the crime committed. The current study assessed shifts in year-to-year changes in incarceration rates within all 50 states from the years 1965 to 2008 due to the adoption of sentencing reforms.
\end{abstract}

Methods: The study tests two competing theories, a normative theory and critical theory of the expected effects of reforms on imprisonment. Data was analyzed using panel regression with unit-specific fixed effects, conditional change scores, panel corrected standard errors, and a new measure of reforms.

Results: This study, possibly due to differences in model specification, ran counter to a number of previous studies and suggests some "front-end" sentencing reforms and "back-end" release changes are, on average, related to changes in imprisonment.

Conclusions: The study concluded, that when significant, reforms increased more than decreased prison growth in comparison to indeterminate sentencing. Additionally, the analysis concludes that changes in release mechanisms and parole decision structures are driving increased growth more than changes in sentencing structures. 


\section{Introduction}

Prior to the 1970s, indeterminate sentencing dominated the United States criminal justice system. This model of justice focused on rehabilitating offenders within prison through work and education programs (Roberts, 1996). In most cases, judges (and in some jurisdictions the jury) were given wide discretion to facilitate the rehabilitation process through sentencing offenders to loose ranges (e.g., 5 to 25 years). Parole boards, acting independently of other parts of the judicial system and largely independent of legislators, then determined if the prisoner had been properly rehabilitated and ready for release. The sentencing model reflected a criminal-centered approach designed to pattern punishment to the offender's rehabilitation needs. But in the late 1960s and early 1970s, critics, including politicians, criminal justice practitioners, social science researchers, and the media advanced a number of purported problems, including complaints about the arbitrary nature of the sentencing procedure, ineffectiveness of treatment and reform programs, cozy correctional facilities, and rampant repeat offenders (Blumstein, Cohen, Martin, \& Tonry, 1983; Reitz, 1995, 1996).

Beginning in the early 1970s, imprisonment began an unprecedented climb that resulted in an almost continual five-fold increase over the last 40 or so years. At the same time that imprisonment was rising, a shift in our criminal justice policies occurred reflecting what was often labeled the "get tough on crime" or "law and order" movement. The origins of the movement are often linked to the decade of the 1960s when increased urban unrest resulted in riots, radical youth and black power movements, assassinations of top political figures, and increased crime rates (Beckett, 1997; LaFree, 1998; O'Brien, 2003). These factors interacted with and were enhanced by media coverage (Scheingold, 1991), public concerns (Warr, 1995), and the political responses to these problems. In a sense, these interactions created a perfect storm that fostered the law and order movement, which called for increased focus on crime and a demand for more punitive sanctions. In response, the federal government formed the President's Commission on Law Enforcement and the Administration of Justice in 1969 and passed legislation establishing the Law Enforcement Assistance Administration - the LEAA - (part of the 
Omnibus Crime Control and Safe Streets Act of 1968). The LEAA provided funds to law enforcement agencies to professionalize their operations and improve their record keeping.

Corresponding to the law and order movement was a rise in crime that began during the $1980 \mathrm{~s}$ and ran through the early 90s before it fell again. The growing concern with crime as a social problem helped generate concerns about the effectiveness of the criminal justice system. The amount of discretion at all levels of the justice system, concerns that some offenders were not receiving stiff enough sentences or were being released too soon, and general issues of fairness for victims and offenders in the criminal justice system were all important issues that took on a new salience during this period (Smith, 2004).

Critics that focused on sentencing structures charged that it allowed far too much disparity in sentencing types and time served. In response, legislators and/or voters passed discretion-limiting sentencing reforms with more pre-determined structures that generally narrowed the sentencing ranges and the ability of officials to deviate from them (Frase, 2005; Stemen, Rengifo, \& Wilson, 2006; Tonry, 2009). While some scholars have pointed to increased imprisonment as a result of sentencing reforms, others have suggested the opposite, indicating no additional increase or even a reduction in growth (Stemen, et al., 2006), producing a canon of prior research that is inconsistent with contradictory results. For example, a recent study by Zhang et al. (2009) using hierarchical linear modeling (HLM) to test a weberian formal rationality theory found that reforms did not account for increases in imprisonment. While their analysis is similar to this study they incorporated a substantially different modeling technique and control variables. Most notably HLM does not account for trending data and possible unit-specific omitted variable bias, two areas that must be addressed (a point this paper will later argue). Zhang, et als. (2009) analysis largely contradicted their predicted outcomes that reforms due to increased predetermined predictable outcomes focused on classes of crime would increase imprisonment. Conversely, D'Alessio and Stolzenberg (1995), using time-series data to assess changes over time, found 
jail populations in Minnesota rose after the passage of sentencing guidelines, but that the effect was mitigated when judges took prison-crowding into account.

Stemen et al. (2006) produced a number of competing results. For example, they found that the combination of determinate sentencing and voluntary sentencing guidelines increased imprisonment at the state level, while those states with a combination of determinate sentencing and presumptive sentencing guidelines had lower imprisonment rates (though neither reform was significantly related). The study by Stemen et al. (2006) is the closest study methodologically to this study. Their analysis used a very similar panel structure, though their analysis includes a number of divergent components, most notably the choice to include fixed effects for time and not for states and their choice to use data in three-year increments. The consideration of fixed-effects is one of the chief specification decisions in panel modeling (Halaby, 2004) and failure to properly specify them can undermine an analysis. The analysis in the present study included fixed effects for states and is one of a number of specifications divergent from the majority of prior research. It is argued in this analysis that the models included are more methodologically sound and more appropriate from a theoretical stance.

The model specifications in this study also included a conditional change-score dependent variable (measured as percent change over time) measured through a three-year moving average. When modeled together with fixed effects for states, the conditional change-score model resulted in measurements of the average change over-time in imprisonment within states controlling for other statelevel time-variant covariates. In an additional divergence from previous research, this analysis incorporated a new measure of reforms as logged growth curves that are more theoretically appropriate. The model represents a significant divergence from previous research and should supply more robust and theoretically appropriate results (Halaby, 2004; Spelman, 2008).

Table 1 About Here 
This study focused on six sentencing reforms passed after 1972, which included sentencing guidelines (divided into presumptive and voluntary); statutory presumptive sentencing; truth in sentencing; determinate sentencing (abolishment of discretionary parole boards); and three strikes laws. These reforms are outlined in Table 1 and it indicates they that now comprise the majority of sentencing structures in the US. The study utilizes two competing theories to hypothesis expected effects. The first, a neo-classical theory, was drawn from critical theories suggesting that the context of the law and order movement and the increased bureaucratization of the justice system combined to fuel passage of reforms that were more punitive and led to higher imprisonment. The second theory was drawn from normative explanations that suggest reforms created a structure that was more responsive in managing prison growth and therefore lower changes in imprisonment would be expected under reforms.

\section{Literature Review}

The majority of previous sentencing reform research, with notable exceptions, falls largely into two broad categories. The first focuses on extra-legal effects such as the influence of race or gender on judicial departures from baseline sentence recommendations (e.g. Johnson, 2006; Kramer \& Steffensmeier, 1993; Kramer \& Ulmer, 1996; Steffensmeier, Ulmer, \& Kramer, 1998; Ulmer \& Kramer, 1998; Wooldredge, 2009; Wooldredge \& Griffin, 2005; Wooldredge, Griffin, \& Rauschenberg, 2005), while the second focuses on the influence of policy changes on sentencing outcomes (e.g. Arvanites \& Asher, 1998; Brewer, Beckett, \& Holt, 1981; D'Alessio \& Stolzenberg, 1995; Frase, 1995, 2005; Griset, 1996; Johnson, 2006; Tonry, 1995a, 1995b). In both cases the body of literature largely utilized data on individual states, counties, or cities. While providing important insights, they are limited to the specific context and sentencing structures of the particular jurisdiction and lack broad cross-sectional applicability. Additionally, the majority lacked a time dimension that restricted their ability to draw 
inferences regarding change over time. While a few studies analyzed year-to-year changes over time, these studies were largely limited to a single state, calling into question their generalizability. ${ }^{1}$

This paper follows a smaller subset of research that analyzed aggregate state level data over time (e.g., Marvell (1995), Nicholson-Crotty (2004), Stemen et al. (2006), Spelman (2009), and Zhang et. al. (2009). The results of these similar "pooled" studies, where cross-sections in the form of states are observed over time as a time series generally, though not universally, suggested reforms specifically targeted at sentencing (e.g., sentencing guidelines and statutory presumptive sentencing) did not directly lead to increased imprisonment. In some cases the studies suggested reforms actually reduced changes in imprisonment. The studies further suggested that the elimination of discretionary parole release (e.g., determinate sentencing) and the adoption of truth in sentencing were more likely to be associated, but the findings were mixed suggesting both increases and decreases. Similar to some of the findings of Stemen et al. (2006), Marvell (1995) found in his study of nine presumptive sentencing guideline states that prison growth slowed when prison capacity was specifically taken into consideration. While this was a comprehensive study covering 1974 to 1990, Marvell's study possessed some limitations, including analysis restricted to nine presumptive guideline states, thus leaving the analysis absent of comparison of non-reform states to formulate conclusions in comparison.

Spelman (2009), Stemen et al. (2006), and Zhang et al.’s (2009) studies are the most similar to this study, analyzing similar reforms with "pooled" data from all 50 states over relatively long periods of time. As previously stated, analysis by both Stemen and colleagues (2006) and Zhang and colleagues (2009) produced rather mixed results and generally indicated that reforms more often reduced, rather than increased, imprisonment. Conversely, Spelman (2009), found that truth in sentencing laws, especially those passed after the 1994 omnibus crime bill, were an important component that explained part of the rise in state imprisonment. Spelman (2009) suggested that truth-in-sentencing resulted in a

\footnotetext{
${ }^{1}$ Preliminary analysis in this study indicated that considerable state-to-state variation existed in imprisonment rates, which further calls into question the generalizability of the single-state approach.
} 
$13 \%$ increase in state imprisonment. While he contends that this reform is more of a reflection of the funds made available through the crime bill and was part of a larger pattern of state revenues driving imprisonment (e.g. if money exists to increase capacity, a state generally does and will convict criminals to fill that capacity), a significant, positive effect of truth-in-sentencing was existent. As Spelman (2008) suggested in a separate article, the contradictory findings of effects on imprisonment may be a product of differential model specification. Specifically, he notes the need to first difference imprisonment data, as the failure to do so can result in spurious findings that misrepresent actual effects of covariates.

\section{Neo-classical Explanations of Reform Impact on Imprisonment}

Blumstein et al. (1983) suggest several reasons for the sentencing reform movement, including prison uprisings (raising questions about rehabilitation), concern about individual rights and the control of discretion, demand for accountability, disillusionment with rehabilitation, disparity and discrimination in sentencing and parole, and crime control. As noted in their study (Blumstein, et al., 1983: 3): "These factors, among others, coalesced into a compelling case against indeterminate sentencing. The indeterminate sentencing system that was all but universally supported in the 1950s had few defenders by the late 1970s." Some scholars suggested that intense public pressure to "do something" aided in the passage of the 1994 Omnibus Crime Bill, which made money available for, among other things, sentencing reforms (Blumstein \& Beck, 1999).

While previous research has produced mixed findings, a number of studies (e.g. Engen \& Gainey, 2000; Engen, Gainey, Crutchfield, \& Weis, 2003; Savelsberg, 1992; Zhang, et al., 2009) have incorporated a similar neoclassical Weberian theory that highlights the reallocation of discretion and power within the bureaucratic structures of sentencing. Savelsberg (1992), for example, argued that sentencing guidelines (and likely other sentencing reforms as well) are an ideal representation of Weber's formal rationality, which creates a distinctive theoretical lens for understanding how sentencing policy was "fixed" or, in other words, how the structure was altered to become more predetermined with 
less discretion. This theory suggests that sentencing reforms represent formal rationality, while indeterminate sentencing is more closely aligned with substantive rationality. Both sentencing procedures are rational as defined by Weber (1978) because they are based in law and thus have "legalized" validity, but differ in their application (i.e. formal vs. substantive) of the laws. Substantive decision-making is subject to values, appeals to ethical norms, and historical precedent with less focus on uniformity of the outcomes. Formal decisions, on the other hand, focus on limiting subjective decision-making by stressing rationalized, structural outcomes that remove personal values by emphasizing a technical orientation to procedural process grounded in well-defined criteria designed to elicit a specific outcome. "The judge . . is more or less an automaton of paragraphs: the legal documents, together with the costs and fees, are dropped in at the top with the expectation that the judgment will emerge at the bottom, together with more or less sound arguments - an apparatus, accordingly, whose functioning is by and large calculable or predictable" (Weber 1978: 17). In the end, social policies such as "fixed" sentencing reforms serve to bureaucratize the process, with the specific goal of removing subjective interpretations and outcomes (Engen \& Gainey, 2000; Zhang, et al., 2009). Scheingold (1991) and Beckett (1997), for example, suggested shifts in sentencing policy represented the concerted effort by policy makers to advance the "justice model" of crime and punishment. This framework focuses on making criminals pay and deterring those who might commit crimes in the future, ${ }^{2}$ with punishment tailored to fit the crime rather than the offender. This more critical theory suggests reforms representing broader social pressures of the law and order movement resulting in a push for more punitive sanctions whereas reforms served as a tool to codify law and order within sentencing.

To understand how increased imprisonment might be connected to sentencing policy impacted by the law and order movement, Scheingold (1991) suggests we must recognize the complex and

\footnotetext{
${ }^{2}$ Some authors like Von Hirsch (1985) would argue that reforms do not represent such a cynical approach, but instead take a more measured, "proportional" structure designed to meet the crime and take on no real deterrence effect (or at least are not explicitly designed to be a deterrent). Authors who advocate a Von Hirsch view of reforms often refer to them as a proportional model.
} 
interactive mechanisms that shape policy change. The interaction includes policy makers at national, state, and local levels, political elites, public opinion, citizen activism, and media responses and representations. A crucial element of this interaction is the public's fear of crime. "[P]olicy changes are mostly likely to occur when political leaders, in part by taking their cues from the media, choose to play upon public anxieties that are themselves inflamed by media imagery and vicarious victimization rather than by crime as such" (Scheingold 1991:44). Gottschalk $(2006,2009)$ notes that prior to the late 1960s, crime rarely registered as a top public issue and not until the law and order movement did the public begin to demand substantial change. Accustomed to further political agendas by playing on public fears of crime (often misrepresenting actual crime rates), politicians advanced an individualistic view of crime as a function of societal deviants. A lack of effective sanctions was seen as part of the problem (Abramsky, 2007; Simon, 2007). Meanwhile, the media continually displayed images of crime, especially images of isolated victims of random violent crime, fueling public fears (Glassner, 1999). In completing the interactive cycle, politicians then seized upon these fears to create platforms focused on getting tough on crime. This complex circle of interactions served to promote and sustain the politicization of crime characterized by the "politics of fear" that stressed "getting tough on crime," resulting in the model of punishment, featuring, among other things, "fixed" sentencing reforms (Beckett, 1997; Simon, 2007).

These historical underpinnings provide some important contexts when considering why reforms were passed and what goals they may have had, but unless reforms were significant in altering the structure, shifts in imprisonment are not likely. For example, if judicial discretion is maintained, then reforms are unlikely to effect change (Doob, 2000; Simon, 2007). If the historical underpinnings are successful in a structural changes (e.g. Weberian formal rationality) that codify the law and order movement then it may be possible that reforms resulted in an increase in imprisonment (Engen \& Gainey, 2000; Savelsberg, 1992). Thus while reforms often had a stated goal of considering impacts on imprisonment, the goal of not increasing it could have been overcome by broader "get tough" demands. 
Thus, the first hypothesized outcome of this study suggests increased focus on formal rational outcomes in sentencing combined with the law and order movement to increase imprisonment in sentencing reform states more than non-reform states.

\section{Normative Theories of Sentencing Growth and Reforms}

Prior research has differed in the theorized outcome of changes to the bureaucratic structure of sentencing. Some research suggested that increased control and more pre-defined sentencing allowed officials (e.g. sentencing commissions, prison officials, or legislators) to better manage prison growth. These authors tended to draw from normative theories that suggest prison growth was the result of other factors like increased criminal activity, spikes in violent crime among young people, or increased social and/or economic instabilities (Von Hirsch, 1985). They then suggested, through highlighting the stated goals of reforms and the general points of emphases within the sentencing system, that reforms were not one of the factors that increased imprisonment. Zimring (2001) suggested that sentencing reforms were not associated with prison growth directly, highlighting that several of the reforms had the stated goal of considering impacts on imprisonment during their construction. Tonry (1997) showed that after Minnesota instituted sentencing guidelines in 1980 their prison population did rise, but at lower rates than the national average and that by 1992, Minnesota had the second lowest rate of imprisonment in the country.

The normative theory that posits sentencing reforms may reduce imprisonment by creating a structure more responsive to external pressures highlights the strain of the contradictions the criminal justice system experienced during the law and order movement. While many politicians and a large portion of the general public began to demand increased awareness of and effective curbing of crime the justice system was often not prepared to respond. Criminal justice officials, especially judges were often resentful of the new approaches and prisons, which were often at or over capacity and lacked the resources to handle more inmates. The tension often resulted in a demand to address the "problem of crime" while not explicitly increasing imprisonment (Engen \& Steen, 2000; Tonry \& Hatlestad, 1997). 
Marvel (1995) found that when states were explicitly directed to consider the impact of presumptive sentencing guidelines on imprisonment that they either maintained or, in some cases, reduced imprisonment. As Marvel suggests it is possible that policy makers decided moderation was necessary to slow growth, as legislators were reluctant to fund the construction of additional prisons.

It is possible sentencing commissions were insolated from the larger demands of the law and order movement and even though politicians and the public may have demanded more prison sentences and more time-served, commissions were able to operate behind the public scrutiny and use the new power over sentencing policies to effectively curb growth. The supporters of the normative theory of reforms suggest the same Weberian formal rationalization process are taking place, but they suggest the process was not necessarily influenced by the "get tough" calls of the law and order movement. The postulate is bolstered by evidence that states with active commissions were often explicitly told that prison growth must be considered when altering sentencing and were less likely to see prison growth (Marvell, 1995; U.S., 1996; Zhang, et al., 2009; Zimring, 2001).

\section{Hypotheses}

This paper used differentiated modeling techniques from previous research to test two competing hypotheses. If the analysis assumes that "fixed" sentencing reforms represented a structural change born under the politics of fear associated with the law and order movement, it is possible that the interaction served to increase imprisonment in states with the sentencing reforms at a greater rate than in states with indeterminate sentencing. Though states not adopting "fixed" sentencing are also likely to be influenced by the sociopolitics of the time, "fixed" reforms are likely to increase imprisonment more by formalizing the sociopolitical environment into practice through their technical-rational bureaucratic structure brought on by their formal rationalization. For example, by limiting the low end of the sentence range, the judge has restricted ability to select lenient sentences for at least some felons (Johnson, Ulmer, \& Kramer, 2008; Savelsberg, 1992). If the analysis follows the normative theories, where reforms served as a way to control spiraling imprisonment caused by other factors, we would expect that sentencing 
reforms reduced changes in imprisonment more than that of non-reform states (Greenberg \& West, 2001; Marvell, 1995; Tonry \& Hatlestad, 1997).

Specifically, it was expected that the adoption of presumptive sentencing guidelines, voluntary sentencing guidelines, statutory presumptive sentencing, truth in sentencing, and determinant sentencing would be associated with imprisonment. The effects of the adoption of three strikes legislation was also analyzed - but an association was less assured. The hesitation in making a prediction in the case of three strikes is related to a number of prior studies indicating that because relatively few criminals, outside of California, Florida, and Georgia were sentenced under the law, it has had little actual substantive impact (Dickey \& Hollenhorst, 1999; Kovandzic, Sloan, \& Vieraitis, 2004). For example, Dickey and Hollenhorst (1999) found that fewer than a hundred inmates were sentenced under three strikes. Additionally, these hypotheses are drawn from theories specific to the U.S. justice system. As Von Hirsch (1985) has pointed out, while many western industrial societies also experienced substantial prison growth, the U.S. maintains a unique system-both structurally and culturally-suggesting the effects are not generalizable to other countries.

\section{Data}

\section{Dependent Variable}

Before 1972, imprisonment rates remained relatively stable over time, but since that year, steady and rapid increases occurred. To measure possible impacts of sentencing reforms on imprisonment the analysis incorporates a dependent variable of total prison population per 100,000. The variable was measured on the state level (all $50^{3}$ states) and was observed over time from 1967 to $2007^{4}$, resulting in 2050 possible observations. This "pooling" of the time-series and cross-sectional data greatly improves the statistical power of the models (Hsiao, 2003; Wooldridge, 1997).

\footnotetext{
${ }^{3}$ Washington, D.C. is often included in analysis of this type (treated as a "fifty-first state"), but was excluded because data for the entire time period in question was not complete. In addition to incomplete data, Washington, D.C. stopped housing its own prisoners in 2001.

${ }^{4}$ Data actually covers the years 1965 to 2008 , but the moving average truncated the data by one year at the beginning and the end. Furthermore, the lagged variables further reduced the measured effects, reducing the actual measured years from 1967 to 2007.
} 
A Dickey Fuller test $(Z(t)=-1.656)$ suggested the presence of a unit-root in the unchanged dependent variable. Furthermore, when the dependent variable was measured as a rate of total imprisonment, there are substantive reasons to believe that a previous year's imprisonment is highly associated with the current year's level. Furthermore previous research has indicated that imprisonment is unit-root at the state-level (Spelman, 2008). Because of the presence of a unit root, the dependent variable was transformed into percent change $\left(\Delta Y=\left(\left(Y_{i t} / Y_{i t-1}\right)-1\right) * 100\right)$, changing the dependent variable to year-to-year change (sometimes referred to as the unconditional change-score, where the score was measured as a percentage) in imprisonment (Finkel, 1995; Halaby, 2004).

Between the years of 1967 and 2007 imprisonment trended up almost 550\%. This created the common time-series specification problem where reforms would likely increase total imprisonment simply because they are clustered on the more recent end of the time-series where the rate of imprisonment is the highest. This is a specification error that must be corrected; fortunately, the firstdifference transformation also corrects for this problem. Unlike the unchanged-score model, the change-score model no longer fails the Dickey Fuller test $(Z(t)=-6.382, P<.01){ }^{5}$

Even in a change-score analysis a shock or spike in the series can undermine the ability of the model to effectively measure change over time. To remedy the apparent shocks observed, a three-year moving average was instituted (Frees, 2004). This helped to alleviate strain on the model and resulted in about a $1 / 4$ reduction in standard errors and about a $10 \%$ increase in R-squared even after the reduction of 100 observations. Thus to facilitate analysis state imprisonment rates were transformed into a percentage change per year and then into a three-year moving average. This allowed for assessment of state-level changes in imprisonment rates over time due to changes in state-level covariates. Data for

\footnotetext{
${ }^{5}$ This is true for both the first differenced and moving averaged variables.
} 
the dependent variable was obtained from the Bureau of Justice Statistics (U.S., 1965-1983, 1984-1998, $1999-2008)^{6}$

\section{Sentencing Reform Variables}

Table 2 outlines the six sentencing reform variables. They were compiled from three sources which included a report from the Bureau of Justice Assistance (1996), an article by Zhang, Maxwell, and Vaughn (2009), and a report by the Vera Institute (Stemen, et al., 2006). While most research is in agreement on the general aim of the various reforms, considerable variation in the design and application exists and there is little consensus on appropriate grouping (Frase, 2005; Marvell, 1995; Stemen, 2007; Tonry, 1995b). This study takes an approach common among the researchers who focused on important legal distinctions among the reforms (distinctions are discussed below).

In a shift away from indeterminate sentencing, sentencing guidelines consist of a matrix of possible sentences with a more narrow range within sentencing categories that are defined by an offender's criminal history (prior offenses) and offense severity. These two main determinates make up the technical apparatus informing the judge's “automation of paragraphs” suggested by Weber (1978). It is important to note that the design and implementation of guidelines vary considerably from state-tostate (Frase, 2005; Stemen, et al., 2006). One classification of guidelines incorporates two loose legal categories. The first, labeled presumptive sentencing guidelines, are "legally binding" where a judge's decision is regulated through appellate review. The second format, voluntary sentencing guidelines, treats guidelines as a formal recommendation, but does not legally mandate that they be followed, as they are not enforced through appellate review. While judges may be required to give a written justification to deviate, they are not legally obligated to follow them and are largely free to render any decision they want (Stemen, et al., 2006). Research does substantiate judges follow the

\footnotetext{
${ }^{6}$ Data for the years of 1972 to 1983 is available in the yearly publication: Prisoners in State and Federal Institutions on December 31,1972 (through 1983). Data for the years of 1984 to 1998 is available in the yearly publication: Correctional Populations in the United States, 1984 (through 1998). Data for the years of 1999 to 2008 is available in the yearly publication: Prisoners, 1999 (through 2008). Rates per 100,000 for each variable was computed by taking the raw number of prisoners for each state by year that was provided by the Bureau of Justice Statistics and dividing by state population per 100,000 as supplied by the Bureau of the Census.
} 
recommendations of voluntary guidelines $85 \%$ of the time, suggesting they do have an impact (Miethe $\&$ Moore, 1988). The bifurcated classification ${ }^{7}$ of presumptive or voluntary is unrelated to how the guidelines were created (by legislative statute, initiative process, or sentencing commission) or whether an active commission monitors them.

\section{Table 2 About Here}

It is important to note that while it is relatively simple to classify guidelines by their binding legal status, considerable variation exists in design and application, both across and within the two types (Frase, 1995, 2005; Reitz, 1995). ${ }^{8}$ As Frase (2005) and Tonry (1995b) argue it may be more appropriate to consider guidelines as falling on a continuum from structured to loose. Many states, like Pennsylvania, while they are legally classified as a presumptive guideline state, have very wide sentencing ranges acting in many ways like a voluntary guideline. Some voluntary systems, as in Missouri, have very limited ranges, giving little leeway to judges who choose to follow them. Many researchers have rightfully acknowledged the "fixedness" of sentencing guidelines varies considerably from state-to-state. Because explanation of the general effects is the primary objective and not the variation within guidelines, the author has chosen to leave further discussion of guidelines diversity to another analysis.

\footnotetext{
${ }^{7}$ A census of the appropriateness of this bifurcation is not uniformly agreed upon and considerable disagreement of the proper way to categorize them still exists. The two "types" discussed here represent a division largely discussed and advocated by Frase (1995) and Stemen et al. (2006) and is the most likely division to be informative in this analysis.

${ }^{8}$ Furthermore, the factors considered during initial adoption varied greatly. For example, stated attempts to be prison growth neutral, designed to be proscriptive vs. prescriptive, and explicit consideration of one or more of the following issues: race, ethnicity, and gender. These state-to-state variations in "design factors" will not be directly assessed in this study, but do represent an area of analysis worthy of investigation. They are not directly assessed in this study for three reasons. First, the analysis is concerned with aggregate data and any further slicing of the independent variables further reduces the predictive power of the analysis. Second, theoretically it is likely that while states have discussed publicly their desires, outcomes will likely vary considerably from their stated goals. Third, individual discussion of isolated states' sociopolitical landscape during adoption is hampered by a lack of available aggregated data.
} 
Statutory presumptive sentencing ${ }^{9}$ was also assessed. It was another attempt to shift away from the indeterminate model. While statutory presumptive sentencing is similar to sentencing guidelines, it is important not to lump them together, as statutory presumptive sentencing represents an attempt to create uniformity within similarly situated crimes, but does not use a sentencing rubric. It specifies an appropriate or "normal" sentence for each offense as a baseline. Other relevant factors (aggravating or mitigating circumstances) may be considered alongside the baseline sentence, but its intent is to "fit the punishment to the crime" rather than "fit the punishment to the offender" (Brewer, et al., 1981; Frase, 1995; Savelsberg, 1992).

This study also assessed determinate sentencing (abolishment of parole) and truth in sentencing laws. In contrast to the three previously mentioned reforms, their focus lies in the "backend" mechanism of release as opposed to the "front-end" of sentencing. Determinate sentencing ${ }^{10}$ is used to refer to a system without discretionary parole boards. Truth in sentencing, on the other hand, does not necessarily dictate the elimination of parole boards, but instead requires offenders to serve a statutorily defined minimum amount of time. Only states that meet the 1994 Omnibus Crime Bill minimum ( $85 \%$ time-served of the original sentence) are considered in this analysis. These reforms, like the front-end reforms, shift the role of sentencing away from a more rehabilitative-indeterminate model. Finally, three strikes laws, which suggest a severe sentence (e.g. 25 to life or a straight life sentence) for a third felony offense, were considered. Due to their focus on habitual offenders, they are considered an additional reform beyond the previous five more structured reforms. They, too, fall under the umbrella of "fixed" reforms because they are designed to limit discretion through an apparent departure from the rehabilitation model (Griset, 1995; Stemen, et al., 2006).

\footnotetext{
${ }^{9}$ As with other sentencing reforms, considerable variation between states adopting statutory presumptive sentencing exists. For this analysis, the important point is that this sentencing procedure again represents a shift from the indeterminate model to a model focused on equalizing the variation in sentencing across similar crimes by "fixing" the sentence to the crime.

${ }^{10}$ The choice of determinate sentencing to represent the elimination of discretionary parole boards is unfortunate and has often led to confusion. The name choice was dictated by policy makers and not chosen by the author of this article. It was decided to leave the name as determinate sentencing, as this is the term most commonly used in the literature.
} 
There are three key points about reforms that should be noted. First, the front-end reforms are mutually exclusive and may not co-exist with each other or indeterminate sentencing. The back-end reforms, if instituted, operate alongside whichever front-end sentencing structure the state employs and may co-exist with each other. Second, because the dependent variable does not include county or local jail populations, only individuals sentenced to more than one year are considered, suggesting a one-year lag (the impact beginning one year after inception). Third, while in the year following the reform there will be an instantaneous effect on some portion of the imprisonment rate, not all individuals in any given year will be "caught up" by the reform. Some of the rate of imprisonment will be individuals who were already imprisoned and sentenced under the previous sentencing procedure. Over time, a greater proportion of prisoners will be "caught up" by the reform. At some point a plateau at nearly full effect will occur and only a small portion of the rate of imprisonment will be individuals sentenced to long terms under indeterminate sentencing. To address both the lagged effect and in order to capture the expected "logged growth curve" like effect, a logarithmic measure of the reforms was instituted (Harmon, 2011). This measure represents an important divergence from many previous analyses, which relied heavily on dummy variables. ${ }^{11}$

To create the new measures, each state was coded as 1.00 in the first year of implementation and as $e(2.71828)$ for year five through the last year of observation. A period of five years was chosen as the period to reach full effect because the average sentence was a little over two and a half years. ${ }^{12}$ The intervening years between one and five were set at an equal distance between 1.00 and 2.71828. Finally, the natural log of each score was taken. This procedure created a "logarithmic growth variable" with a one-year lag (the $\log$ of 1 is 0$)$ that suggests full effect at five years (ln of 2.71828 is 1$)$. The measure represents an effect that approaches 1 (the full effect) at an increasingly diminished rate (increased fast

\footnotetext{
${ }^{11}$ Coding the reforms as dummy variables (zero before adoption and 1 after adoption) suggests imprisonment rates would be affected $100 \%$ by the new policy in the first year it was adopted.

${ }^{12}$ While the effects are likely to vary from state-to-state, the lack of specific knowledge of the effect in any given state necessitates a general measure representing all reforms. That being said, this measure is likely an improvement over previous reforms.
} 
at first and then slowed). ${ }^{13}$ The state-by-year observations with indeterminate sentencing were coded to zero and represented the reference group.

\section{Control Variables}

The control variables were grouped into three main areas of influence. The first area, crime controls, was measures by arrests for violent crime ${ }^{14}$ and drug crime. The FBI's Uniform Crime Report (UCR) (1965-2008b) supplied the data and were then converted into state-specific rates using census data (U.S. 1965-2008). The crime variables represented a theory that arrests had a direct effect on changes in state imprisonment. Simply put, states with more crime had larger increases in imprisonment over time. This theory necessitates that the crime variables be lagged, as crime rates are not likely to have an "instantaneous" effect on imprisonment, as those arrested will undoubtedly take time to be processed through the system. The variables were transformed into a percent change score $(\Delta X=$ $\left.\left(\left(X_{i t} / X_{i t-1}\right)-1\right) * 100\right)$ to avoid any issues due to trends in arrests. The models could have included un-lagged crime controls, but this would suggest a "simultaneous" effect. While possible, for example, if higher crime created social pressure to "do something about it", it was less likely (DeFina \& Arvanites, 2002).

The second group of controls included five demographic variables. The U.S. Census (19652008) ${ }^{15}$ supplied data for percent Black, percent Hispanic, and percent urban, and also supplied state population which was used to construct all rate variables. While percent urban was also transformed into a percent change score in the same way that the arrest variables were, percent Black and percent Hispanic were not. While percent urban trended up over time necessitating the transformation into

\footnotetext{
${ }^{13}$ The models were run using two different measures of reforms not presented in this paper to assess the robustness of the "growth-like effect" of reforms. The first used dummy codes to represent reforms. These models had similar point estimates, but generally had significantly inflated standard errors. The inflated errors make sense if the dummy variables are overestimating the effect of reforms in the early years of adoption as argues in this paper. The second additional specification included non-limited variables that continued the logarithmic increase over the entire life of the reform. The last specification again produced similar point estimates but had larger standard errors. It should be noted that the non-limited variables version errors were not as large as the dummy variables suggesting that dummy codes are the least appropriate measure.

${ }^{14}$ Violent crime arrests represent UCR indexed crimes and include the offenses of murder, forcible rape, robbery, and aggravated assault.

${ }^{15}$ Data from the census was compiled from both census data and population estimates.
} 
percent change, percent Black and Hispanic ${ }^{16}$ were more stable within states (though they vary considerably from state-to-state) and did not change considerably over time where high percent states remained high while low percent states remained low. The last two demographic variables, unemployment rate and percent under the poverty line-were supplied by the U.S. Bureau of Labor Statistics (1965-2008a) and U.S. Bureau of the Census (2006), respectively, and were also not transformed, as they also did not trend substantially over time.

The third set of controls includes political variables. Dubin (2007) supplied the needed data for political party affiliation of each state senate and house (or assembly). ${ }^{17}$ The dummy code for the political party of the Governor of each state was obtained from Hershey (2007). The political variables were also lagged in this analysis, suggesting that it takes at least two years for political control to impact state operations. The final political variable, state revenue, was included because policy decisions are, in part, influenced by resources (Spelman, 2009). Vera Institute (Stemen, 2007) supplied yearly data on revenues. It was then converted into rates per 100,000 using census data, adjusted for inflation to 2008 U.S. dollars. State revenues represent all state dollars collected from taxes and other resources per year. Research indicates that all three sets of controls represent key areas of association with imprisonment, warranting their inclusion in this analysis (Barker, 2006; Beckett \& Western, 2001; Blumstein \& Beck, 1999; Parker \& Horwitz, 1986; Raphael, 2009; Spelman, 2009).

\section{Methods}

To analyze changes in state imprisonment rates due to the adoption of sentencing reforms, a Time-Series Cross-Section (TSCS) Regression technique utilizing Panel Corrected Standard Errors (PCSE) was employed. In the standard panel specification, panel errors are prone to problems of

\footnotetext{
${ }^{16}$ In an analysis not presented Percent Black and Percent Hispanic were logged resulting in slightly different results, but the substantive finding remained the same.

${ }^{17}$ State house and senate variables were constructed by centering the percent Republican around 50\% so that Republican control represents positive deviations from 50\%, while Democratic control represents negative deviations. The absolute value of the deviations were then logged, with the negative sign return for the Democratic control, to create a logarithmic scale with positive and negative deviation from zero to represent the diminishing returns of political party concentrations (see Harmon 2011).
} 
heteroskedasticity and autocorrelation. PCSE are helpful in alleviating these problems improving reliability of the standard errors (Beck \& Katz, 1995; Hsiao, 2003; Wooldridge, 1995).

While PCSE corrects some of the potential issues with the standard errors, it does not solve all issues associated with the complicated analysis. Omitted state-level variables that are stable over time and correlated with the error term of the dependent variable (omitted variable bias) can make point estimates biased and, if present in the model (e.g. the random-effects model: $Y=\beta_{0}+\beta_{1} X_{1 i t} \ldots \beta_{\text {nit }}+$ $\left.v_{i}+\varsigma_{t}+\varepsilon_{i t}\right),{ }^{18}$ must be corrected. A Hausman test $\left(\chi^{2}=59.74, P<.001\right)$ comparing a unit-fixedeffects model to a random-effects model suggested that omitted bias was present. Therefore, a unitfixed-effect model, which holds the unexplained time-invariant variation constant, controlling for the unobserved state level effects, was incorporated through inclusion of 50-1 $\left(e . g ., i_{i} \ldots i_{i-1}\right)^{19}$ dummy variables for each state. While the unit (panel-specific) fixed-effects model is statistically necessary in this analysis, it also sacrifices little in substantive interpretation because the primary concern is not with panel-to-panel variation. Instead, the interest lies in aggregate change over time within states. In fact, the panel-specific fixed-effects approach measures exactly that: the change in the dependent variable within each panel where the coefficients give us the aggregate within-state change over time for the average within-state change in the independent variables (England, Kilbourne, Farkas, \& Dou, 1988; Halaby, 2004; Wooldridge, 1997, 2005). Substantively, this was where the expected effect of reforms that are state (panel) specific was located.

A second Hausman test comparing the unit-specific fixed effects model (with a change-scored dependent variable as a three-year moving average) to the full fixed effects model (including both time and unit fixed effects) suggested that the model was consistent under the unit-specific model. Additionally, because theory suggests it is desirable to preserve the measure of change over time and

\footnotetext{
${ }^{18}$ Where $v_{i}$ is the unobserved time-invariant variation, $\varsigma_{t}$ is the unobserved case-invariant variation and $\varepsilon_{i t}$ is the idiosyncratic error term. $\varepsilon_{i t}$ is assumed to be uncorrelated with $X_{1 i t} \ldots X_{n i t}$ and with $v_{i}$ and $\varsigma_{t}$ and where $v_{i}$ and $\varsigma_{t}$ are not correlated with $X_{1 i t} \ldots X_{n i t}$.

${ }^{19}$ Because $i_{i} \ldots i_{i-1}$ and $\beta_{0}$ are perfectly correlated with $v_{i}, v_{i}$ drops from the analysis
} 
that dummy variables for time would reduce efficiency and introduce multicolinearity, it was decided not to include fixed-effects for years (Allison, 2009; Finkel, 1995; Halaby, 2004).

It is likely the unit-specific fixed effects model is more desirable given the results of the second Hausman test, but a full fixed effects model with both time and unit fixed effects may still be justified. If year-to-year changes that affect states equally is occurring such that it is causing significant enough time-specific unit-invariant (e.g. a national effect) omitted variable bias than the consistency of the point estimates could be undermined. In this situation the full fixed effects model would be necessary. While a Hausman test gives some evidence to the contrary, running both models will give better insight into any possible national effect. Thus a full fixed effects model that included 41-1 (e.g. $\left.t_{t} \ldots t_{t-1}\right)^{20}$ dummy variables for time in addition to the 50-1 (e.g., $\left.i_{i} \ldots i_{i-1}\right)$ dummy variables for each state was also be presented.

Statistically, change scores are not without their limitations. In the unconditional change score model if the explanatory variables are related to the initial values of the dependent variables, a phenomenon known as regression to the mean, biased results can occur. To correct for this, a lagged term of imprisonment rate (unchanged, e.g. $Y_{i t-1}$ and not $\Delta Y_{i t-1}$ ) was included as a control variable. This model is often referred to as the static-score or conditional change-score model and "frames the analysis in the following fashion: do the independent $X$ variables [both $X$ or $\Delta X$ ] influence changes in $Y$ (e.g. $\Delta Y$ ) for fixed levels of $Y_{t-1}$, that is, taking into account the negative effect of initial values of $\mathrm{Y}$ (represented by $\beta_{n+1} Y_{i t-1}$ ) on subsequent change." (Finkel, 1995: 9). In effect, this analysis can be viewed as 50 simultaneous, first-differenced (measured though a three-year moving average), timeseries regressions that produce coefficients that represent the average effect of reforms on the average state (Finkel, 1995; Frees, 2004). The model, $\Delta Y=\beta_{0}+\beta_{1 i t} \ldots \beta_{n i t}+\beta_{n+1} Y_{i t-1}+i_{1} \ldots i_{n-1}+\Delta \zeta_{t}+$ $\varepsilon_{i t}$, supplied considerable advantages, yielding consistent and efficient, yet conservative, point estimates that were both theoretically desirable and statistically robust. The full fixed effects model,

\footnotetext{
${ }^{20}$ Because $t_{t} \ldots t_{t-1}$ and $\beta_{0}$ are perfectly correlated with $\Delta \varsigma_{t}, \Delta \varsigma_{t}$ drops from the analysis
} 
$\Delta Y=\beta_{0}+\beta_{1 i t} \ldots \beta_{n i t}+\beta_{n+1} Y_{i t-1}+i_{1} \ldots i_{n-1}+t_{t} \ldots t_{t-1}+\varepsilon_{i t}$, produces similar point-estimates under an even more conservative approach that controls for unexplained unit-invariant variation by dropping $\Delta S_{t}$ through the inclusion of $t_{t} \ldots t_{t-1}$. This model is not without its costs as it reduces efficiency and may introduce multicolinearity that could make the results unreliable. Fortunately the conditional change-score model may help to limit the effects of any unit specific omitted variable bias, reducing the necessity of the full fixed effects model.

\section{RESULTS}

Table 3 presents the results for three models testing the two competing hypotheses. The models measured the increase or decrease in the change in the average imprisonment rate due to the move from indeterminate sentencing (the reference group) to one or more sentencing reform, controlling for other covariation. As noted earlier, an important consideration of this analysis is that all states during the period after 1972 experienced imprisonment growth, regardless if they had passed a reform or not. In fact indeterminate sentencing states, on average, increased imprisonment by about $4.5 \%$ per year (or 9.1 inmates per 100,000). Higher percent change in imprisonment, indicated by positive coefficients, (when a reform has been implemented) indicates higher increases, on average, beyond the $4.5 \%$. Conversely, negative coefficients indicate that reforms resulted in a state that grew imprisonment at a rate lower than $4.5 \%$ (e.g. $\left.4.5 \%-\beta_{\text {nit }}\right)$ after the reform was implemented. While it is theoretically possible for a reform to reduce overall imprisonment (stock imprisonment rates), only when a combination of reforms results in more than a $4.5 \%$ reduction in year-to-year change will it actually reduce stock imprisonment.

Model 1 analyzes only the six reforms and the 11 controls, treating each reform as a discrete independent effect. The results of this model should be interpreted with some care, as in the vast majority of cases, a state did not enact just a single reform and interactions between the reforms are likely present. The results do indicate some interesting findings. First, as independent effects, only one of the front-end reforms-statutory presumptive sentencing and one of the back-end reforms, truth in sentencing-was significant. Both grew imprisonment more than indeterminate sentencing, though the 
effect sizes differed sizably. For example, on average, when statutory presumptive sentencing is at full effect $(\ln (2.71828)$ or 1$)$ the average year-to-year change in imprisonment was about $7.7 \%{ }^{21}$, while in indeterminate states it was about $4.5 \%$, approximately a three-quarter increase in inmates per year. Conversely, in truth-in-sentencing states, the change in imprisonment was about $5.7 \%$ or growing about three-quarters the percent of statutory presumptive sentencing. Truth-in-sentencing percentage of growth was still twenty-five percent more, per year, than indeterminate sentencing. Interestingly, sentencing guideline (both presumptive and voluntary), were the only reforms (in both models), as a main effect, to suggest lower growth in imprisonment, although the effect was not significant.

\section{Table 3 About Here}

Because most states adopted more than one reform, interaction effects are likely. Model 2 added first-level interaction terms to the reform variables found in Model 1. Keeping with convention, nonsignificant interaction coefficients were left in the models because significant interactions were expected (Jaccard \& Turrisi, 2003). In this model, on their own as main effects, statutory presumptive sentencing $(8.8 \%)$ and truth in sentencing $(7.3 \%)$ continued to significantly increase changes in imprisonment rates. The coefficients suggest, when these two reforms are fully implemented, they increased in imprisonment by a factor of 1.96 and 1.62 per year, respectively, over indeterminate sentencing. While not significant when modeled without interaction terms (Model 1), determinate sentencing and three strikes, as a main effects, significantly increased imprisonment when modeled with interactions (Model 2). The finding that three strikes was significant is curious considering previous research suggested little actual effect of this reform. It is possible the significant impact of three strikes was related to the high coexistence of it with other reforms. Only four of the 24 three-strike states implemented this single reform. In the other 21 states, at least one other reform (in most cases more than one additional reform) was implemented. It

\footnotetext{
${ }^{21}$ The average growth of a reform was calculated by adding the coefficient for the reform to the average effect of $4.5 \%$ from the reference group of indeterminate sentencing. For example, $7.7 \%$ was calculated by adding $4.5 \%+3.2 \%$.
} 
is possible that the significant coefficient simply represents an interaction of three strikes with the other reforms. This assertion is supported by the non-significant effect of three strikes in Model 1 and the numerous significant interactions terms in Model 2. Finally in Model 2, as a main effect, the sentencing guidelines variables are no longer negative. This suggests, as main effects, that all six reforms increase imprisonment independent of each other. Of course, the impact of the main effects should be viewed with care as in only rare occasions did a state adopt only one reform. Additionally, the presence of multiple reforms is likely to lead to differing impacts based on the combination they appear in.

The interaction terms presented in Model 2 bring to light a number of important considerations. First, the reforms have vastly different effects depending on the combination they are implemented in. For example, when statutory presumptive sentencing is paired with truth in sentencing and treated as interacting with each other, the interaction term, serving as a mitigating effect, reduced the combined conditional main effect. Thus, while statutory presumptive sentencing and truth in sentencing increased sentencing $8.8 \%$ and $7.3 \%$ respectively, when both reforms are present the increase is mitigated by the interaction term of -2.773 . This "mitigating effect" resulted in an increase of only $7.9 \%{ }^{22}$ suggesting the "co-existing" reforms did not possess a purely linear additive property. This discovery furthers the assertion that the interactions of reforms are an important consideration. While it should be noted that not all interaction terms were significant, they had a profound effect. In some cases the interaction terms increased the main effects, but in most cases the interaction terms served as a mitigating effect. In fact, in some combinations the mitigating effect was so strong the combined reforms served to slow growth in imprisonment over indeterminate sentencing. For example, in states with presumptive guidelines and truth in sentencing growth was about $3.7 \%$ per year or about $20 \%$ lower growth than the average indeterminate state. The interaction of voluntary sentencing guidelines and three strikes laws was even more powerful and reduced growth by almost half to $2.5 \%$.

\footnotetext{
$227.9 \%=4.5 \%$ (percent change in imprisonment under indeterminate sentencing) $+4.3 \%$ (main effect of statutory presumptive sentencing) $+1.8 \%$ (main effect of truth in sentencing) $+-2.8 \%$ (interaction of statutory presumptive sentencing and truth in sentencing).
} 
To illustrate how the reforms impacted imprisonment growth quite differently when taken in different combination, the average effect of sentencing reforms on aggregate changes in imprisonment over time for states adopting the six reforms (singularly or in combination) is outlined in Table 4 . The scores presented are percent change in year-to-year imprisonment, using the coefficients from Model 2. The scores are the predicted change from indeterminate sentencing $(4.5 \%)$. The predicted change-scores represent the average modification from indeterminate sentencing in year-to-year percent-change in imprisonment rates for the average state adopting some combination of reforms. Thus positive coefficients increase imprisonment above $4.5 \%$ per year, while negative coefficients results in slower growth. Table 4 highlights that in the majority of the cases, reforms-singularly or in combinationincreased changes in imprisonment (though often not significantly). Though some combinations of reforms resulted in lower changes, these cases were rarer. No combination resulted in actual reductions in stock imprisonment, e.g. resulted in a predicted score less than $4.5 \%$ and thus reducing overall imprisonment. While not uniform across all combinations including sentencing guidelines, only in reform combinations where at least one of the sentencing guideline types was present was a year-to-year change in imprisonment lower than indeterminate sentencing. This finding is also supported by negative (though not significant) coefficients found in Model 1 and supportive of some prior research (e.g. Marvell, 1995).

Another important observation from Table 4s illustration of the interaction of reforms was the powerful impact of the "back-end" reforms. In general, as a state added additional back-end reforms, imprisonment tended to grow at higher percentages. Policymakers may want to take note of this important observation as it indicates that once a state already has a front-end reform as it adds additional backend reforms, states, on average, send about one-quarter to a third more inmates a year to prison. While there are a few cases where adding additional back-end reforms actually lowered the number of inmates, this was limited to five interactions and only in the combination of presumptive sentencing guidelines and determinate sentencing which occurred for a limited amount of time in only Minnesota 
and Oregon (both states later adopted additional reforms that then increased imprisonment again) was the reduction significant. Of the front-end reforms statutory presumptive sentencing, which was largely adopted in the 1970s, had a profound effect, doubling the number of inmates going to prison. While the other two front-end reforms, both types of sentencing guidelines, had a more modest effect, the addition of back-end reforms played similarly to all three. First, year-to-year changes in imprisonment slowed when a state added determinate sentencing, but tended to grow more when either or both truth in sentencing and three strikes were added, with or without determinate sentencing. This is another important note for policymakers as this indicates that the most significant modern (statutory presumptive sentencing was largely passed in the 70s and early 80s) contributor to imprisonment growth is truth in sentencing and to a lessor extent three strikes laws (though the later may be a function of their interaction with front-end reforms and not the reform itself). This is especially true when these reforms are taken in combination with a preexisting front-end reform.

Models 2 also included the 11 crime, demographic, and political control variables ${ }^{23}$ found in Model 1 (the coefficients in Model 1 are presented in Table 3 but were not discussed). Historical and contemporary research had shown that high rates of violent crime increased state imprisonment (Irwin \& Austin, 1997; Mauer, 2002; Raphael, 2009; Steffensmeier \& Demuth, 2000). Arrests for drug crimes are also essential to understanding the effect of reforms. The war on drugs was a key component of the law and order movement, and the criminal justice system increased criminalization and punishment for various drug crimes, especially possession. As a result, in 2008, drug crime convictions constituted onefifth of state prison populations, a twenty-fold increase from 1980 (Crow \& Gertz, 2008; Crow \& Johnson, 2008; Karnig \& Mcclain, 1985). As expected, the lagged percent change in drug arrests was significantly related to changes in imprisonment, suggesting increased arrests for drugs increased the change in imprisonment within states. Violent crime arrests, on the other hand, were not significant.

\footnotetext{
${ }^{23}$ In a model not presented in Table 3 that included only the reform variables and their interactions the analysis explained about $54 \%$ of the variation. This suggests the control variables are explaining $11 \%$ of the overall variation.
} 
Surprisingly only one of the demographic variables-percent black-significantly increased change in imprisonment. Two of the political variables, Republican State House and Republican Governors increased changes. While it is likely that the social pressure to get tough on crime cuts across political parties, imprisonment rose more under Republicans, supporting some previous research (Davey, 1998; Jacobs \& Helms, 1996). Spelman (2009) has argued that state spending was the single most important factor in increasing imprisonment. While his research also indicated that reforms, particularly truth in sentencing (which increased imprisonment by 13\%) increased imprisonment, state spending increased imprisonment (by 29\%) more than any other factor. The research here indicates that state revenue was not significantly associated, possibly suggesting a different effect. Though the difference may also be due to a slightly different measure in Spelman's analysis. He used state spending as opposed to state revenue, while highly correlated they are not exactly the same and might account for the difference.

Plumper and Troeger (2007) note a unit-fixed effects model alone does not correct for possible unit-invariant omitted variable bias. To illustrate the possible impacts of any national effect that might produce unit-invariant omitted variable bias leading to unreliable results, Model 3 adds fixed effects for years to Model 2. The results were quite similar suggesting that Model 2 was appropriate. This was likely given the results of the Hausman test prior to analysis.

The full-fixed effects model does indicate a relatively large increase in R-squared, from 0.486 in Model 2 to 0.626 in Model 3. This increase may seem substantial by indicating that a fairly large amount of unit-invariant omitted variation is present. While technically true, we must caution against jumping to this conclusion without further exploration. First, it is important to recognize that fixedeffects, while it controls for unobserved variation caused by our ignorance to properly specify all variation that could otherwise be measure (e.g. omitted variable bias), fixed effects only allows us to 
specify the place of our ignorance (with the important "byproduct" of controlling for omitted variable bias). That is, it tells us if it is either time-invariant or unit-invariant, but does not tell us what specifically is going on (it gives where, but not what). Thus, in this cause we now know that $14 \%$ of the unexplained variation in our model is "located" in time, but for us to actually alleviate our ignorance we would have to add additional variables. Second, and possibly a more important consideration of our ignorance specification is if this unit-invariant omitted variable bias is leading to inconsistent pointestimates. While likely a significant problem in the traditional OLS random effects model with or without unit fixed-effects. It is worthy mentioning again that the unit-specific fixed effects model in this analysis is not simply a pooled OLS regression model. The results presented in Model 2 include panel corrected standard with conditional change-scores, with the later specification likely alleviating much of the bias causing covariation with our unspecified time-variant ignorance. As indicated by the Hausman test the unit-specific fixed effects model is consistent suggesting that when all of the model specifications of this analysis are incorporated time-variant omitted variable bias is not undermining Model 2 and the discussion of Table 4.

There were some changes from Model 2 to Model 3 of note. The most notable change was in the increased standard errors of many of the coefficients. This was likely caused by two major factors.

First, was a, albeit relatively small, reduction in the degrees of freedom by the inclusion of $40\left(t_{t} \ldots t_{t-1}\right)$ additional covariates. Second, and possibly more important, was a likely increase in multicolinearity. As, Halaby (2004) details the inclusion of fixed effects for time, while it likely corrects for unit-invariant omitted variables bias, it has a tendency to lead to variables with small unit-to-unit differences, including in this analysis many of the reform and some of the controls variables, to be substantially correlated with the dummy variables for time. This may best be illustrated by the increase in the standard errors of the reform variables, as they are particularly likely to be correlated. 


\section{DISCUSSION}

This analysis has advantages over some previous research. First, the analysis included a long time period of historically relevant data that is current to 2007. The "imprisonment binge" began roughly in the early 1970s with 1972 often cited as the "start date" (Blumstein \& Beck, 1999; DeFina \& Arvanites, 2002). With data beginning in 1967 it allowed for analysis prior to and after the start of the binge, improving the overall model. Additionally, data for every year was included, which covered the effects more accurately than previous studies using more limited 3, 5, or 10-year gaps (Wooldridge, 2002). Second, this analysis included six major sentencing reforms and first level interactions, a marked advantage over some previous research that has included fewer reforms and, at times, failed to interact them. As seen in this analysis, considerable change in the effects are observed when different combinations of the reforms are considered and failure to account for this in previous research may have miss-specified the true impact. Third, the analysis included both cross-sectional and time-series data giving it a marked advantage over analysis that lacked one of these dimensions. Finally, the modeling technique employed takes a step away from previous research and supplies a unique, yet arguably better, analysis that incorporates, among other things, conditional change-scores, fixed-effects for states, and the logged growth curve variables for reforms.

Some researchers, however, have argued that the type of analysis in this study is undermined by the variation in reforms from state-to-state, both in what was adopted and in functional operation. For example, not all presumptive sentencing guidelines are the same with some having tight ranges and some having wide ranges. This type of variation is inherent and unavoidable as rarely will two policies enacted by different states be exactly the same. But policy-to-policy variation alone is not enough to discount the results. While the policy variation may make the models less efficient, meaning larger standard errors that reduce the likelihood of finding significant relationships, they do not make them less accurate, because as long as the variables are properly specified, the point estimates are still consistent. That being said, the analysis does not allow complete state-by-state analysis (e.g. we can not definitely 
calculate the change over time for Oregon vs. Washington) or conclude that all states or even one particular state observed the effects. The analysis does, on the other hand, allow the conclusion that, on the aggregate or on average, a reform is (or is not) significantly associated with changes in imprisonment within states. The coefficients represent the average treatment effect across states which does have important substantive interpretation, outlining the average change over time within states (Finkel, 1995).

Additionally, while it might seem logical to advocate for more delineation among the six reforms, such a move is not without its statistical costs. Disaggregating the variables into smaller and smaller groups reduces the statistical power of "pooling" data over time, which is one of the main advantages of TSCS modeling. The ability to get significant results would succumb to an increased "slicing" of the data. This highlights the delicate balance of variable specification and statistical power that is often weighed in these types of models (Wooldridge, 2000). The specifications of the reform variables in this analysis were made in an attempt to maximize statistical power while maintaining meaningful outcomes.

The statistical modeling is one of the areas where this study differs from the three previous studies with the most similarities (e.g. Spelman, 2009; Stemen, et al., 2006; Zhang, et al., 2009) and may account for the dissimilarities found. The use of conditional change-scores, measured as percent change, was a notable component of this analysis. As Spelman (2008) and Frost (2008) highlighted, the choice of measurements can have a profound impact and change-scores more accurately specify year-toyear changes in imprisonment. Previous studies have tended to use trending imprisonment rates, overlooking the need to address this specification error. Additionally, Spelman (2008) and Halaby (2004) suggested that many previous studies, including some studies of imprisonment, have chosen to include random effects models and unchanged or stock imprisonment data. These previous studies have often failed to account for issues of omitted bias, unit-roots, and serial correlated errors, which can all lead to substantially biased point estimates. This study took a different approach, incorporating 
methodological advantages that may better represent the true nexus of the reform effects on imprisonment. In the end, the model "sacrificed" efficiency, which can lead to more significant results, to "protect" the integrity (consistency) of the coefficients against biased point estimates. This more “conservative” approach likely produced more reliable and valid results.

\section{CONCLUSION}

The central finding of this investigation is that some "fixed" sentencing reforms significantly impacted changes in imprisonment rates over time, indicating they led to larger aggregate changes under some conditions, while reducing them under other conditions. While Boerner and Lieb (2001) make note of a few states that had not seen specific direct prison growth, this analysis suggests otherwise. In general, as highlighted in Table 4 (though not always significantly supported), the presence of statutory presumptive sentencing, truth in sentencing, or three strikes, though not without exception, tended to increase the change in imprisonment. Though it should be noted that impact of three strikes was relatively small, while generally growing more than indeterminate sentencing, the growth rate was lower for combinations of reforms with three strikes than without. For example, while the main effect of three strikes significantly increased imprisonment when this reform is taken in combination with other reforms, it generally did not result in additionally higher changes. In isolation, statutory presumptive sentencing resulted in an $8.8 \%$ yearly increase in imprisonment, but when three strikes was present the yearly change was actually slightly less at $8.2 \%$. In only four of the 24 states were only three strikes adopted, which stresses the need to consider the impact of interactions between reforms. Overall, the analysis suggested a weak general effect of three strikes laws.

The tendency of statutory presumptive sentencing, truth in sentencing, or three strikes to increase imprisonment more was observed in most cases, except when sentencing guidelines was present. While in both models the main effects of sentencing guidelines failed to be significant, there were occasions where their interactions were significant. Additionally, in Model 2 and 3 the main effects of sentencing guidelines were positive (though not significant), but when taken in combination with other reforms, 
they tended to reduce imprisonment growth over indeterminate sentencing. It is important to note that with exception of one state, Arkansas, the passage of sentencing guidelines was always accompanied by an additional back-end reform. The profound effect the interactions had in this case may explain the negative coefficients in Model 1. The findings related to sentencing guidelines represent the only place in the analysis that supports the normative theory of reforms that suggested reforms would create opportunities to limit prison growth. In this sense, the findings are not inconsistent with Marvell's (1995) earlier finding that presumptive sentencing guidelines reduced imprisonment in six of nine states he studied.

The findings suggest that reforms, generally outside of sentencing guidelines, increased imprisonment more than indeterminate sentencing. The findings were not completely unexpected. For example, while Spelman (2009) concluded that state revenues were chief among factors leading to prison growth, he did show that reforms were related, particularly truth in sentencing laws. Thus in a sense, the analysis here supports his findings on this one front, especially considering the possibility that reforms were among many factors that led to prison growth, and in some cases, this may have been even counter to the reforms intended outcome. On the other hand, the findings here do not support his contention that state resources were driving imprisonment growth.

Another important impact of Spelman's (2009) findings was the relative speed by which truth in sentencing was adopted after the passage of the Omnibus Crime Bill. Spelman (2009) suggests that the bill resulted in more resources for the states and this translated into higher imprisonment. While his resource contention is plausible, it also highlights the need to consider federal resources and federal imprisonment when assessing state imprisonment. While states have seen significant prison growth, federal growth has been even higher in recent years, rising over 80\% between 1995 and 2005 (U.S., 1965-2008b). Half of all inmates in federal prison are incarcerated due to drug crimes (Hebert, 1997), and it is possible that these federal changes had a trickle-down effect on state imprisonment. Future research may want to consider these important federal influences. 
Overall, while in some combinations the reforms suggest a reduction in prison growth, supporting the normative theory of reforms, the analysis was more consistent with the neoclassical theories that suggests the context of the law and order movement combined with the increased objectivity of the shift to a more formal-rational system of sentencing increased imprisonment more in reform states. This analysis, with the preponderance of evidence on the side of the neoclassical argument, is at odds with some previous research. Stemen et al. (2006) and Zhang et al. (2009) found that in some combinations, determinate sentencing actually reduced imprisonment. The findings here give some very limited support for this contention, but otherwise the findings, including the results that suggest statutory presumptive sentencing and truth in sentencing increased imprisonment, run counter. Again, the differences may, in part, be driven by the methodological differences between these previous studies and this one. For example, when the models in this analysis are run without fixed-effects for states a number of the reforms-including presumptive sentencing guidelines (a finding of Marvell's (1995) study) and determinate sentencing-significantly reduced changes in imprisonment, though as argued, the exclusion of fixed-effects for states would be in error. Additionally, the models included logged growth curve variables to represent reforms, a relatively new measure. Previous research has, to date, generally included dummy variables, which may misrepresent the "growth like" effects discussed. $^{24}$

States generally began the reform movement on the front-end then moved to back-end. Sixtynine percent of states passed a front-end reform before the 1994 Omnibus Crime Bill, while 70 percent of back-end reforms were passed after the bill. In general, as a state added additional back-end reforms, when they already possessed a front-in reform or another back-end reform, they increased imprisonment changes more, suggesting a "piling-on effect". Alaska and Rhode Island were the only states of the 29 to pass a front-end reform not to add at least one back-end reform, with most passing at least two. The piling-on is highlighted nicely by the interactions of the back-end reforms in Table 4 where two-reform

\footnotetext{
${ }^{24}$ When the models were ran with dummy variables (results not shown) the analysis was similar, but not identical, with some differences in the size of the coefficients.
} 
states had higher growth than one-reform states, and three-reform states had higher growth than two reform states. Policy-makers may want to acutely consider this finding as these back-end reforms may have counteracted slower prison growth imbedded in a front-end reform. The curtailing of these backend reforms may help slow growth and give states a chance to control spiraling costs. This may be particularly relevant for determinate sentencing where parole boards could help control prison growth. Their elimination may have hastened the growth of other reforms. The costs of locking criminals up is increasingly expensive and "prison beds" are currently at critical levels in a number of states (Jacobs \& Carmichael, 2001; Shane-DuBow, 1998). The overall costs of imprisonment growth to individual states can be high. While variation from state to state exists, the average cost per inmate across all states in 2003 was $\$ 22,650$ indicating rising imprisonment is costly (Boerner \& Lieb, 2001). The costs are even higher when capital costs of more jails and prisons are added to the equation. Additionally, increased imprisonment places resource pressures on public defenders and the courts. Rapid increases in prison populations can be devastating to a system that is often slow to respond (Kruttschnitt, 2005).

The results presented here have useful policy and theoretical implications. In all cases, with the exception of some cases where sentencing guidelines were enacted (though even in some cases where they were enacted), the analysis points to a support of the general theoretical arguments that the law and order movement of the mid 1970s to today was, in part, driving a shift to the "justice model" of imprisonment that included "fixed" sentencing (Scheingold, 1991). The reforms served to change the process, through the bureaucratization of the system as described by Weber (1978) and others, from a system giving significant leeway to judges and in house prison officials to a system largely placing power into hands of elected political officials (e.g. legislators and prosecutors) ultimately creating a system that is more susceptible to political and social pressures (Savelsberg, 1992). The theory suggests that under these conditions an increase in punitive incarceration could be expected in which "fixed" sentencing represents a way to codify the punitiveness. These increases are likely regardless of the stated political purposes or goals of the reforms (e.g., desire to be growth-neutral). An important area 
for future research is to assess the key state-level contexts and social structures that are likely to influence the adoption and implementation of reforms. The current project suggests general theoretical arguments for possible mechanisms at work, but more direct assessment is needed. 


\section{References}

Abramsky, S. (2007). American Furies : Crime, Punishment, and Vengeance in the Age of Mass Imprisonment. Boston: Beacon Press.

Allison, P. D. (2009). Fixed Effects Regression Models. Los Angeles: Sage.

Arvanites, T. M., \& Asher, M. A. (1998). State and Country Incarceration Rates: The Direct and Indirect Effects of Race and Inequality. American Journal of Economics and Sociology, 57(2), 207-221.

Barker, V. (2006). The Politics of Punishing - Building a State Governance Theory of American Imprisonment Variation. Punishment \& Society-International Journal of Penology, 8(1), 5-32.

Beck, N., \& Katz, J. N. (1995). What to Do (and Not to Do) with Time-Series Cross-Section Data. American Political Science Review, 89(3), 634-647.

Beckett, K. (1997). Making Crime Pay : Law and Order in Contemporary American Politics. New York: Oxford University Press.

Beckett, K., \& Western, B. (2001). Governing Social Marginality: Welfare, Incarceration, and the Transformation of State Policy. Punishment and Society, 3, 43-59.

Blumstein, A., \& Beck, A. J. (1999). Population Growth in U.S. Prison Populations, 1980-1996. In M. H. Tonry \& J. Petersilia (Eds.), Crime and Justice: A Review of Research (Vol. 26, pp. 17-61). Chicago: University of Chicago Press.

Blumstein, A., Cohen, J., Martin, S. E., \& Tonry, M. H. (Eds.). (1983). Research on Sentencing: The Search for Reform (Vol. Volume 1). Washington D.C.: National Academy Press.

Boerner, D., \& Lieb, R. (2001). Sentencing Reform in the Other Washington. Crime and Justice: $A$ Review of Research, 28, 71-136.

Brewer, D., Beckett, G. E., \& Holt, N. (1981). Determinate Sentencing in California the 1st Years Experience. Journal of Research in Crime and Delinquency, 18, 200-231.

Crow, M., \& Gertz, M. (2008). Sentencing Policy and Disparity: Guidelines and the Influence of Legal and Democratic Subcultures. Journal of Criminal Justice, 36(4), 362-371.

Crow, M., \& Johnson, K. (2008). Race, Ethnicity, and Habitual-Offender Sentencing: A Multilevel Analysis of Individual and Contextual Threat. Criminal Justice Policy Review, 19, 63-83. 
D'Alessio, S. J., \& Stolzenberg, L. (1995). The Impact of Sentencing Guidelines on Jail Incarceration in Minnesota. Criminology, 33(2), 283-302.

Davey, J. D. (1998). The Politics of Prison Expansion: Winning Elections by Waging War on Crime. Westport, CT: Praeger.

DeFina, R. H., \& Arvanites, T. M. (2002). The Weak Effect of Imprisonment on Crime: 1971-1998. Social Science Quarterly, 83(3), 635-653.

Dickey, W. J., \& Hollenhorst, P. (1999). Three-Strikes Laws: Five Years Later. Corrections Management Quarterly, 3(3), 1-18.

Doob, A. N. (2000). Transforming the Punishment Environment: Understanding Public Views of What Should be Accomplished at Sentencing. Canadian Journal of Criminology-Revue Canadienne De Criminologie, 42, 323-340.

Dubin, M. J. (2007). Party Affiliations in the State Legislatures : A Year by Year Summary, 1796-2006. Jefferson, N.C.: McFarland.

Engen, R. L., \& Gainey, R. R. (2000). Modeling the Effects of Legally Relevant and Extralegal Factors Under Sentencing Guidelines: The Rules Have Changed. Criminology, 38(4), 1207-1229.

Engen, R. L., Gainey, R. R., Crutchfield, R. D., \& Weis, J. G. (2003). Discretion and Disparity Under Sentencing Guidelines: The Role of Departures and Structured Sentencing Alternatives. Criminology 41, 99-130.

Engen, R. L., \& Steen, S. (2000). The Power to Punish: Discretion and Sentencing Reform in the War on Drugs. American Journal of Sociology, 105, 1357-1395.

England, P., Kilbourne, B. S., Farkas, G., \& Dou, T. (1988). Explaining Occupational Sex Segregation and Wages - Findings from a Model with Fixed Effects. American Sociological Review, 53, 544558.

Finkel, S. E. (1995). Causal Analysis with Panel Data. Thousand Oaks, Calif.: Sage Publications.

Frase, R. S. (1995). State Sentencing Guidelines - Still Going Strong. Judicature, 78(4), 173-180.

Frase, R. S. (2005). State Sentencing Guidelines: Diversity, Consensus, and Unresolved Policy Issues. Columbia Law Review, 105(4), 1190-1232. 
Frees, E. W. (2004). Longitudinal and Panel Data: Analysis and Applications in the Social Sciences. Cambridge, UK ; New York: Cambridge University Press.

Frost, N. A. (2008). The Mismeasure of Punishment. Punishment \& Society-International Journal of Penology, 10(3), 277-300.

Glassner, B. (1999). The Culture of Fear : Why Americans are Afraid of the Wrong Things (1st ed.). New York, NY: Basic Books.

Gottschalk, M. (2006). The Prison and the Gallows : The Politics of Mass Incarceration in America. New York ; Cambridge: Cambridge University Press.

Gottschalk, M. (2009). Money and Mass Incarcaration: The Bad, The Mad, and Penal Reform. Criminology and Public Policy, 8(1), 97-109.

Greenberg, D. F., \& West, V. (2001). State Prison Populations and their Growth, 1971-1991. Criminology, 39(3), 615-653.

Griset, P. L. (1995). Determinate Sentencing and Agenda Building - a Case-Study of the Failure of a Reform. Journal of Criminal Justice, 23, 349-362.

Griset, P. L. (1996). Determinate Sentencing and Administrative Discretion Over Time Served in Prison: A Case Study of Florida. Crime and Delinquency, 42, 127-143.

Halaby, C. (2004). Panel Models in Sociological Research: Theory into Practice. Annual Review of Sociology, 30, 507-544.

Harmon, M. G. (2011). The Imprisonment Race: Unintended Consequences of "Fixed” Sentencing on People of Color over Time. Journal of Ethnicity in Criminal Justice, 9(2), 79-109.

Hebert, C. (1997). Sentencing Outcomes of Black, Hispanic, and White Males Convicted Under Federal Sentencing Guidelines. Criminal Justice Review, 22, 133-156.

Hershey, M. R. (2007). Party Politics in America (12th ed.). New York: Pearson Longman.

Hsiao, C. (2003). Analysis of Panel Data (2nd ed.). Cambridge ; New York: Cambridge University Press.

Irwin, J., \& Austin, J. (1997). America's Imprisonment Binge. Belmont, CA: Wadsworth Pub. Co. 
Jaccard, J., \& Turrisi, R. (2003). Interaction Effects in Multiple Regression (2nd ed.). Thousand Oaks, Calif.: Sage Publications.

Jacobs, D., \& Carmichael, J. T. (2001). The Politics of Punishment Across Time and Space: A Pooled Time-Series Analysis of Imprisonment Rates. Social Forces, 80, 61-89.

Jacobs, D., \& Helms, R. (1996). Toward a Political Model of Incarceration: A Time-Series Examination of Multiple Explanations for Prison Admission Rates. American Journal of Sociology, 102, 323357.

Johnson, B. (2006). The Multilevel Context Of Criminal Sentencing: Integrating Judge- And CountyLevel Influences. Criminology, 44(2), 259-298.

Johnson, B., Ulmer, J., \& Kramer, J. (2008). The Social Context of Guidelines Circumvention: The Case of Federal District Courts. Criminology, 46(3), 737-783.

Karnig, A. K., \& Mcclain, P. D. (1985). The New South and Black Economic and PoliticalDevelopment - Changes from 1970 to 1980. Western Political Quarterly, 38, 539-550.

Kovandzic, T. V., Sloan, J. J., \& Vieraitis, L. M. (2004). "Striking Out" As Crime Reduction Policy: The Impact of "Three Strikes" Laws on Crime Rates in US Cities. Justice Quarterly, 21(2), 207239.

Kramer, J., \& Steffensmeier, D. (1993). Race and Imprisonment Decisions. Sociological Quarterly, 34, $357-376$.

Kramer, J., \& Ulmer, J. (1996). Sentencing Disparity and Departure from Guidelines. Justice Quarterly, $13,81-105$.

Kruttschnitt, C. (2005). Imprisoning America: The Social Effects of Mass Incarceration. Contemporary Sociology-a Journal of Reviews, 34, 549-551.

LaFree, G. (1998). Losing Legitimacy: Street Crime and the Decline of Social Institutions in America. Boulder: Westview.

Marvell, T. B. (1995). Sentencing Guidelines and Prison Population-Growth. Journal of Criminal Law \& Criminology, 85(3), 696-709.

Mauer, M. (2002). Analyzing and Responding to the Driving Forces of Prison Population Growth. Criminology \& Public Policy, 1(3), 389-392. 
Miethe, T. D., \& Moore, C. A. (1988). Officals' Reactions to Sentencing Guidelines. Journal of Research in Crime and Delinguency, 25, 170-187.

Nicholson-Crotty, S. (2004). The Impact of Sentencing Guidelines on State-Level Sanctions: An Analysis Over Time. Crime \& Delinquency, 50(3), 395-411.

O'Brien, R. M. (2003). UCR Violent Crime Rates, 1958-2000: Recorded and Offender-Generated Trends. Social Science Research, 32(3), 499-518.

Parker, R. N., \& Horwitz, A. V. (1986). Unemployment, Crime, and Imprisonment: A Panel Approach. Criminology, 24, 751-774.

Plumper, T., \& Troeger, V. (2007). Efficient Estimation of Time-Invariant and Rarely Changing Variables in Finite Sample Panel Analyses with Unit Fixed Effects. Political Analysis, 15(2), 124-139.

Raphael, S. (2009). Explaining the Rise in U.S. Incarceration Rates. Criminology \& Public Policy, 8(1), 87-95.

Reitz, K. (1995). State and Federal Sentencing Guidelines: What's Working? What Isn't. Judicature, 78, 207-211.

Reitz, K. (1996). Sentencing Matters. Journal of Criminal Law and Criminology, 86(4), 1585-1602.

Roberts, J. V. (1996). Public Opinion, Criminal Record, and the Sentencing Process. American Behavioral Scientist, 39, 488-499.

Savelsberg, J. (1992). Law That Does Not Fit Society: Sentencing Guidelines as a Neoclassical Reaction to the Dilemmas of Substantivized Law. American Journal of Sociology, 97(5), 1346-1381.

Scheingold, S. A. (1991). The Politics of Street Crime: Criminal Process and Cultural Obsession. Philadelphia: Temple University Press.

Shane-DuBow, S. (1998). The Development of Structured Sentencing: Long-Term Effects and Outcomes. Law and Policy, 20, 383-531.

Simon, J. (2007). Governing Through Crime: How the War on Crime Transformed American Democracy and Created a Culture of Fear. Oxford ; New York: Oxford University Press. 
Smith, K. B. (2004). The Politics of Punishment: Evaluating Political Explanations of Incarceration Rates. Journal of Politics, 66(3), 925-938.

Spelman, W. (2008). Specifying the Relationship Between Crime and Prisons. Journal of Quantitative Criminology, 24(2), 149-178. doi: 10.1007/s10940-008-9042-x

Spelman, W. (2009). Crime, Cash, and Limited Options: Explaining the Prison Boom. Criminology and Public Policy, 8(1), 29-77.

Steffensmeier, D., \& Demuth, S. (2000). Ethnicity and Sentencing Outcomes in U.S. Federal Courts: Who is Punished More Harshly? American Sociological Review, 65(5), 705-729.

Steffensmeier, D., Ulmer, J., \& Kramer, J. (1998). The Interaction of Race, Gender, and Age in Criminal Sentencing: The Punishment Cost of Being Young, Black, and Male. Criminology, 36(4), 763797.

Stemen, D. (2007). Impact of State Sentencing Policies on Incarceration Rates in the United States, 1975-2002. from Inter-university Consortium for Political and Social Research

Stemen, D., Rengifo, A., \& Wilson, J. (2006). Of Fragmentation and Ferment: Impact of State Sentencing Policies on Incarceration Rates in the United States, 1975-2002. Washington DC: National Institute of Justice.

Tonry, M. (1995a). Malign Neglect: Race, Crime and Punishment in America New York: Oxford University Press.

Tonry, M. (1995b). Twenty Years of Sentencing Reform: Steps Forward, Steps Backward. Judicature, $78,169-172$.

Tonry, M. (2009). Explanations of American punishment policies A national history. Punishment \& Society-International Journal of Penology, 11(3), 377-394.

Tonry, M., \& Hatlestad, K. (1997). Building Sentencing Reform in Overcrowded Times: A Comparative Perspective. New York: Oxford University Press.

U.S. (1965-69, 1971-1979, 1981-1989, 1991-1999, 2001-2008). Bureau of the Census, Population Esitmates (On Line). Washington DC.

U.S. (1965-1983). Bureau of Justice Statistics, Prisoners in State and Federal Institutions on December 31, 1965 (through 1983). Washington DC. 
U.S. (1965-2008a). Bureau of Labor Statistics, Geographic Profile of Employment and Unemployment, 1965 (through 2008) U.S. Department of Labor. Washington, D.C.

U.S. (1965-2008b). Federal Bureau of Investigation, Uniform Crime Reporting Program Data, 1965 (through 2008). Washington DC.

U.S. (1970, 1980, 1990, 2000). Bureau of the Census, United States Census (Corresponding Year) on CD-ROM. Washington DC.

U.S. (1984-1998). Bureau of Justice Statistics, Correctional Populations in the United States, 1984 (throught 1998). Washington DC.

U.S. (1996). Bureau of Justice Assistance, National Survey of Sate Sentencing Structures. Wahingtion, D.C.

U.S. (1999-2008). Bureau of Justice Statistics, Prisoners, 1999 (through 2008). Washington D.C.

U.S. (2006). Bureau of the Census, Historical Poverty Tables, 2004 (On Line). Washington DC.

Ulmer, J., \& Kramer, J. (1998). The Use and Transformation of Formal Decision-Making Criteria: Sentencing Guidelines, Organizational Contexts, and Case Processing Strategies. Social Problems, 45(2), 248-267.

Von Hirsch, A. (1985). Past or Future Crimes: Deservedness and Dangerousness in the Sentencing Of Criminals. New Brunswick: Rutgers University Press.

Warr, M. (1995). Public Opinion on Crime and Punishment. Public Opinion Quarterly, 59(3), $296-310$.

Weber, M. (1978). Economy and Society: An Outline of Interpretive Sociology. Berkeley: University of California Press.

Wooldredge, J. (2009). Short- Versus Long-Term Effects of Ohio's Switch to More Structured Sentencing on Extralegal Disparities in Prison Sentences in an Urban Court. Criminology and Public Policy, 8(2), 285-312.

Wooldredge, J., \& Griffin, T. (2005). Displaced Discretion Under Ohio Sentencing Guidelines. Journal of Criminal Justice, 33(4), 301-316. 
Wooldredge, J., Griffin, T., \& Rauschenberg, F. (2005). (Un)anticipated Effects of Sentencing Reform on the Disparate Treatment of Defendants. Law \& Society Review, 39(4), 835-873.

Wooldridge, J. M. (1995). Selection Corrections for Panel-Data Models under Conditional Mean Independence Assumptions. Journal of Econometrics, 68(1), 115-132.

Wooldridge, J. M. (1997). Multiplicative Panel Data Models Without the Strict Exogeneity Assumption. Econometric Theory, 13(5), 667-678.

Wooldridge, J. M. (2000). A Framework for Estimating Dynamic, Unobserved Effects Panel Data Models with Possible Feedback to Future Explanatory Variables. Economics Letters, 68(3), 245250.

Wooldridge, J. M. (2002). Econometric Analysis of Cross Section and Panel Data. Cambridge: MIT Press.

Wooldridge, J. M. (2005). Fixed-Effects and Related Estimators for Correlated Random-Coefficient and Treatment-Effect Panel Data Models. Review of Economics and Statistics, 87(2), 385-390.

Zhang, Y., Maxwell, C. D., \& Vaughn, M. S. (2009). The Impact of State Sentencing Policies On the US Prison Population. Journal of Criminal Justice, 37(2), 190-199.

Zimring, F. E. (2001). The New Politics of Criminal Justice. In D. Garland (Ed.), Mass Imprisonment in the USA (pp. 145-149). London: Sage. 
Table 1. Distribution of Sentencing Types Across the United States as of 2008

\begin{tabular}{|c|c|c|c|c|c|c|}
\hline & $\begin{array}{c}\text { Presum. } \\
\text { Guide. }\end{array}$ & Vol Guide. & $\begin{array}{c}\text { Stat. } \\
\text { Presum. }\end{array}$ & Deter. Sent. & $\begin{array}{c}\text { Truth in } \\
\text { Sent. }\end{array}$ & $\begin{array}{l}\text { Three } \\
\text { Strikes }\end{array}$ \\
\hline \multirow{51}{*}{$\begin{array}{l}\text { Alabama } \\
\text { Alaska } \\
\text { Arizona } \\
\text { Arkansas } \\
\text { California } \\
\text { Colorado } \\
\text { Connecticut } \\
\text { Delaware } \\
\text { Florida } \\
\text { Georgia } \\
\text { Hawaii } \\
\text { Idaho } \\
\text { Illinois } \\
\text { Indiana } \\
\text { Iowa } \\
\text { Kansas } \\
\text { Kentucky } \\
\text { Louisiana } \\
\text { Maine } \\
\text { Maryland } \\
\text { Massachusetts } \\
\text { Michigan } \\
\text { Minnesota } \\
\text { Mississippi } \\
\text { Missouri } \\
\text { Montana } \\
\text { Nebraska } \\
\text { Nevada } \\
\text { New Hampshire } \\
\text { New Jersey } \\
\text { New Mexico } \\
\text { New York } \\
\text { North Carolina } \\
\text { North Dakota } \\
\text { Ohio } \\
\text { Oklahoma } \\
\text { Oregon } \\
\text { Pennsylvania } \\
\text { Rhode Is. } \\
\text { South Carolina } \\
\text { South Dakota } \\
\text { Tennessee } \\
\text { Texas } \\
\text { Utah } \\
\text { Vermont } \\
\text { Virginia } \\
\text { Washington } \\
\text { West Virginia } \\
\text { Wisconsin } \\
\text { Wyoming } \\
\text { Total }\end{array}$} & - & 2006 & - & - & - & - \\
\hline & - & - & 1980 & - & - & - \\
\hline & - & - & 1978 & 1994 & 1994 & - \\
\hline & - & 1994 & - & - & - & 1995 \\
\hline & - & - & 1976 & 1976 & 1994 & 1994 \\
\hline & - & - & 1979 & $79-85$ & - & 1994 \\
\hline & - & - & - & $81-90$ & 1995 & 1994 \\
\hline & - & 1987 & - & 1990 & 1990 & - \\
\hline & 1994 & 1983-93 & - & 1983 & 1995 & 1995 \\
\hline & - & - & - & - & 1995 & 1995 \\
\hline & - & - & - & - & - & - \\
\hline & - & - & - & - & - & - \\
\hline & - & - & - & 1978 & - & - \\
\hline & - & - & 1977 & 1977 & - & 1994 \\
\hline & - & - & - & - & 1996 & - \\
\hline & 1993 & - & - & - & 1993 & 1994 \\
\hline & - & - & - & - & - & - \\
\hline & - & 1987 & - & - & - & 1994 \\
\hline & - & - & - & 1976 & 1995 & - \\
\hline & - & 1983 & - & - & - & 1994 \\
\hline & - & - & - & - & - & - \\
\hline & 1999 & 1984-98 & - & - & 1994 & - \\
\hline & 1980 & - & - & 1982 & 1993 & - \\
\hline & - & - & - & 1995 & 1995 & - \\
\hline & - & 1997 & - & - & 1994 & - \\
\hline & - & - & - & - & - & 1995 \\
\hline & - & - & - & - & - & - \\
\hline & - & - & - & - & - & 1995 \\
\hline & - & - & - & - & - & - \\
\hline & - & - & 1977 & - & - & 1995 \\
\hline & - & - & 1977 & 1977 & - & 1994 \\
\hline & - & - & - & - & 1995 & - \\
\hline & 1995 & - & - & 1981 & 1994 & 1994 \\
\hline & - & - & - & - & 1995 & 1995 \\
\hline & 1996 & - & - & 1996 & 1996 & - \\
\hline & - & - & - & - & - & - \\
\hline & 1989 & - & - & 1989 & 1995 & - \\
\hline & 1982 & - & - & - & 1991 & 1995 \\
\hline & - & - & 1981 & - & - & - \\
\hline & - & - & - & - & - & 1995 \\
\hline & - & - & - & - & 1996 & - \\
\hline & 1989 & - & - & - & 1995 & 1995 \\
\hline & - & - & - & - & - & - \\
\hline & - & 1985 & - & - & 1985 & 1995 \\
\hline & - & - & - & - & - & 1995 \\
\hline & - & 1995 & - & 1995 & 1995 & 1994 \\
\hline & 1984 & - & - & 1984 & 1984 & 1993 \\
\hline & - & - & - & - & - & - \\
\hline & - & $85-94 \& 99$ & - & - & 1999 & 1994 \\
\hline & - & - & - & - & - & - \\
\hline & 10 & 11 & 8 & 18 & 24 & 24 \\
\hline
\end{tabular}

Note: Table 1 represents the current sentencing type used by each state as of 2008. Presum. Guide. stands for presumptive sentencing guidelines. Vol. guide. Stands for voluntary sentencing guidelines. Stat. Presum. stands for statutory presumptive sentencing. Deter. Sent. stands for determinate sentencing. Truth in sent. stands for truth in sentencing. Three strikes refers to three strikes laws. All other states utilize indeterminate sentencing. 
Table 2. The Six Reforms Included in Analysis

\begin{tabular}{|l|l|}
\hline Reform & Description \\
\hline Guidelines $^{1}$ & $\begin{array}{l}\text { Consists of a matrix of possible sentences with a more } \\
\text { narrow range within a sentencing category that is } \\
\text { defined by an offender's criminal history (prior } \\
\text { offenses) and offense severity then indeterminate } \\
\text { sentencing. Judges generally must follow the matrix as } \\
\text { the sentence is enforced through appellate review. }\end{array}$ \\
\hline $\begin{array}{l}\text { Goluntary Sentencing } \\
\text { Guidelines }\end{array}$ & $\begin{array}{l}\text { Treat guidelines as formal recommendation, but does } \\
\text { not legally mandate they be followed by the judge. } \\
\text { That is, while judges generally follow them, an } \\
\text { offender may not appeal deviations from the matrix }\end{array}$ \\
\hline $\begin{array}{l}\text { Statutory Presumptive } \\
\text { Sentencing }\end{array}$ & $\begin{array}{l}\text { Represent an attempt to create uniformity within } \\
\text { similarly situated crimes, but acts less like a sentencing } \\
\text { rubric. It specifies an appropriate or "normal" sentence } \\
\text { for each offense as a baseline for a judge. }\end{array}$ \\
\hline Determinate Sentencing \\
\hline Truth in Sentencing
\end{tabular}

${ }^{1}$ Front-End Reforms ${ }^{2}$ Back-End Reforms ${ }^{3}$ Sentencing Enhancement 
Table 3. The effects of sentencing reforms on changes in imprisonment over time: 1967-2007

\begin{tabular}{|c|c|c|c|c|c|c|}
\hline \multirow[b]{2}{*}{ Reforms } & \multicolumn{2}{|c|}{$\begin{array}{c}\text { Fixed Effects: } \\
\text { States Only } \\
\end{array}$} & \multicolumn{2}{|c|}{$\begin{array}{l}\text { Fixed Effects: } \\
\text { States Only }\end{array}$} & \multicolumn{2}{|c|}{$\begin{array}{c}\text { Fixed Effect: } \\
\text { States \& Time }\end{array}$} \\
\hline & Model 1 & S.E. & Model 2 & S.E. & Model 3 & S.E. \\
\hline Pres. Sent. Guidelines & -1.055 & $(0.855)$ & 1.127 & $(1.508)$ & 1.512 & $(1.591)$ \\
\hline Voluntary Sent. Guidelines & -0.312 & $(0.473)$ & 0.361 & $(0.492)$ & 0.475 & $(1.203)$ \\
\hline Statutory Presumptive Sent. & $3.241 * * *$ & $(0.990)$ & $4.336^{*}$ & $(2.165)$ & $2.373^{* *}$ & $(0.907)$ \\
\hline Determinate Sentencing & 0.578 & $(1.021)$ & $1.926^{*}$ & $(0.811)$ & 1.593 & $(1.159)$ \\
\hline Truth in Sentencing. & $1.190^{*}$ & $(0.496)$ & $1.838^{* *}$ & $(0.679)$ & $1.764 *$ & $(0.813)$ \\
\hline Three Strikes & 0.688 & $(0.441)$ & $1.467^{*}$ & $(0.602)$ & 0.629 & $(0.441)$ \\
\hline \multicolumn{7}{|l|}{ Interaction Terms } \\
\hline Pres. Guide * Determ. Sent. & - & - & $-5.033^{* * *}$ & $(1.245)$ & $-4.210^{*}$ & $(1.724)$ \\
\hline Pres. Guide * Truth in Sent. & - & - & -3.171 & $(2.154)$ & $-4.819^{*}$ & $(2.459)$ \\
\hline Pres. Guide * Three Strikes & - & - & 2.368 & $(2.084)$ & 2.265 & $(3.050)$ \\
\hline Vol. Guide * Determ. Sent. & - & - & $-3.135^{* * *}$ & $(0.788)$ & -1.489 & $(1.436)$ \\
\hline Vol. Guide * Truth in Sent. & - & - & $-0.837^{*}$ & $(0.470)$ & $-1.141^{*}$ & $(0.585)$ \\
\hline Vol. Guide * Three Strikes & - & - & $-1.975^{*}$ & $(0.791)$ & $-1.357 * *$ & $(0.589)$ \\
\hline Stat. Pres. * Determ. Sent. & - & - & $-5.256^{*}$ & $(2.607)$ & $-2.373^{*}$ & $(1.181)$ \\
\hline Stat. Pres. * Truth in Sent. & - & - & $-2.773 *$ & $(1.411)$ & $-2.873^{*}$ & $(1.453)$ \\
\hline Stat. Pres. * Three Strikes & - & - & $-2.112 * * *$ & $(0.617)$ & $-2.320 * * *$ & $(0.740)$ \\
\hline Det. Sent. * Truth in Sent. & - & - & $1.776^{* *}$ & $(0.551)$ & $2.170^{*}$ & $(1.117)$ \\
\hline Det. Sent. * Three Strikes & - & - & 0.347 & (1.609) & 0.497 & $(1.979)$ \\
\hline Truth * Three Strikes & - & - & $0.290^{*}$ & $(0.151)$ & 0.279 & $(0.217)$ \\
\hline \multicolumn{7}{|l|}{ Crime Controls } \\
\hline Violent Crime (Lagged) & -0.0167 & $(0.019)$ & -0.0186 & $(0.019)$ & -.00155 & $(0.003)$ \\
\hline Drug Crime (Lagged) & $0.00209 * * *$ & $(0.001)$ & $0.00221 * * *$ & $(0.001)$ & $-.00199 *$ & $(0.0009)$ \\
\hline \multicolumn{7}{|l|}{ Demographic Controls } \\
\hline Percent Black & 0.124 & $(0.111)$ & $0.412 * * *$ & $(0.121)$ & 0.052 & $(0.049)$ \\
\hline Percent Hispanic & -0.132 & $(0.087)$ & -0.0129 & $(0.075)$ & 0.072 & $(0.080)$ \\
\hline Percent Unemployment & -0.198 & $(0.130)$ & -0.186 & $(0.127)$ & 0.077 & $(0.108)$ \\
\hline Percent Poor & 0.0035 & $(0.074)$ & 0.012 & $(0.070)$ & 0.0071 & $(0.014)$ \\
\hline Percent Urban & -0.0051 & $(0.013)$ & -0.0029 & $(0.013)$ & -0.002 & $(0.004)$ \\
\hline \multicolumn{7}{|l|}{ Political Controls } \\
\hline Rep. St. House (Lagged) & $0.569 * * *$ & $(0.119)$ & $0.552 * * *$ & $(0.131)$ & $0.516^{* * *}$ & $(0.186)$ \\
\hline Rep. St. Senate (Lagged) & 0.106 & $(0.132)$ & 0.0601 & $(0.136)$ & 0.139 & $(0.178)$ \\
\hline Rep. Governor (Lagged) & $0.828^{* *}$ & $(0.297)$ & $0.667^{*}$ & $(0.311)$ & $0.558^{*}$ & $(0.271)$ \\
\hline State Revenues (Lagged) & 0.193 & $(0.180)$ & 0.103 & $(0.187)$ & 0.280 & $(0.156)$ \\
\hline $\begin{array}{l}\text { Lagged Dependent Variable } \\
\text { Observations } \\
\text { R-Squared }\end{array}$ & $\begin{array}{l}-0.0177 * * * \\
2024 \\
0.435\end{array}$ & $(0.003)$ & $\begin{array}{l}-0.0185^{* * *} \\
2024 \\
0.486\end{array}$ & $(0.003)$ & $\begin{array}{l}-0.0338^{* * *} \\
2024 \\
0.626\end{array}$ & $(0.003)$ \\
\hline
\end{tabular}

Standard errors in parentheses

$* * * \mathrm{p}<0.001, * * \mathrm{p}<0.01, * \mathrm{p}<0.05$ 
Table 4. Estimated Aggregate Percent Change Over Time of Reforms by Themselves or in Combination with Other Reforms.

\begin{tabular}{|c|c|c|c|c|c|c|c|c|}
\hline & & 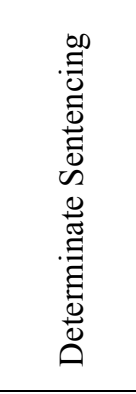 & 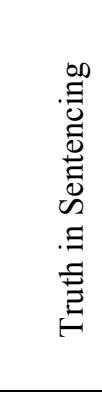 & 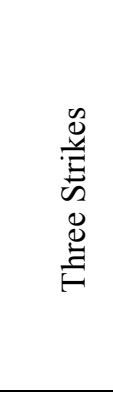 & 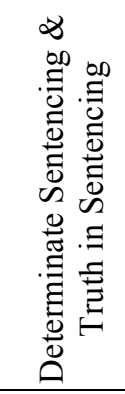 & 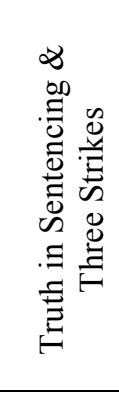 & 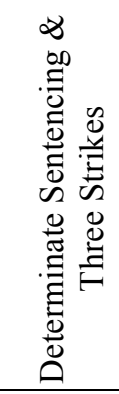 & 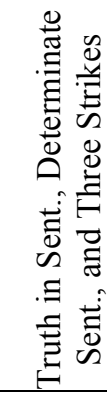 \\
\hline \multirow[b]{2}{*}{ Presumptive Sent. Guide. } & 1.13 & $-1.98 *$ & -0.21 & 4.97 & -1.54 & 2.80 & 2.21 & $2.94 *$ \\
\hline & $(1.51)$ & $(1.02)$ & $(0.17)$ & $(3.43)$ & $(1.24)$ & $(1.62)$ & $(1.38)$ & $(1.56)$ \\
\hline \multirow{2}{*}{ Voluntary Sent. Guide. } & 0.37 & -0.85 & 1.37 & -0.15 & $1.93 *$ & $1.16^{* *}$ & -1.01 & $2.06^{*}$ \\
\hline & $(0.49)$ & $(1.28)$ & $(1.69)$ & $(0.80)$ & $(1.09)$ & $(0.56)$ & $(0.82)$ & $(1.16)$ \\
\hline \multirow{2}{*}{ Statutory Presump. Sent. } & $4.34^{*}$ & $1.01 * * *$ & $3.41^{\wedge}$ & 3.70 & $1.85^{*}$ & 3.05 & $0.71 *$ & $1.84^{\wedge}$ \\
\hline & $(2.17)$ & $(0.20)$ & $(1.96)$ & $(3.21)$ & $(0.99)$ & $(2.66)$ & $(0.34)$ & (1.19) \\
\hline \multirow[t]{2}{*}{ Determinate Sentencing } & $1.93^{*}$ & & $5.55^{\wedge}$ & 3.75 & & 7.65 & & \\
\hline & $(0.81)$ & & $(3.01)$ & $(2.76)$ & & $(5.82)$ & & \\
\hline \multirow[t]{2}{*}{ Truth in Sentencing } & $1.84^{*}$ & $5.55^{\wedge}$ & & 3.60 & & & 7.65 & \\
\hline & $(0.68)$ & $(3.01)$ & & $(4.15)$ & & & $(5.82)$ & \\
\hline \multirow[t]{2}{*}{ Three Strikes } & $1.47 *$ & 3.75 & 3.60 & & 7.65 & & & \\
\hline & $(0.60)$ & $(2.76)$ & $(4.15)$ & & $(5.82)$ & & & \\
\hline Indeterminate Sentencing & $4.505^{1}$ & & & & & & & \\
\hline
\end{tabular}

Notes: The coefficients represent the average (of the aggregate state) change over time in imprisonment rate per 100,000 state populations controlling for the variables presented in Model 2 of Table $3 .{ }^{1}$ Indeterminate sentencing was calculated by setting each of the reform variables to zero. Italicized reforms indicate reforms or combinations in which change in sentencing was lower than indeterminate sentencing. Standard error in parentheses and were calculated using STATA's lincom command. *** $\mathrm{p}<0.001, * * \mathrm{p}<0.01, * \mathrm{p}<0.05, \wedge \mathrm{p}<0.10$ 